\title{
NUTRITIONAL PROFILE OF ASYMPTOMATIC ALCOHOLIC PATIENTS
}

\author{
Maria Beatriz SOBRAL-OLIVEIRA ${ }^{1}$, Joel FAINTUCH ${ }^{1}$, Dulce Reis GUARITA², \\ Claudia P. OLIVEIRA ${ }^{3}$ and Flair J. CARRILHO ${ }^{4}$
}

\begin{abstract}
Context - Alcoholism may interfere with nutritional status, but reports are often troubled by uncertainties about ingested diet and organ function, as well as by ongoing abuse and associated conditions. Objective - To identify nutritional and body compartment changes in stable alcoholics without confounding clinical and dietetic variables, a prospective observational pilot study was designed. Three well-matched populations were considered: subjects with chronic alcoholic pancreatitis, alcoholics without visceral disease, and healthy never-drinking adults (controls). Methods - Subjects $(\mathrm{n}=60)$ were asymptomatic males with adequate diet, no superimposed disease or complication, and alcohol-free for at least 6 months. After exclusions, 48 patients were compared. Variables encompassed dietary recall, bioimpedance analysis, biochemical profile and inflammatory markers. Main outcome measures were body fat, lean body mass, serum lipids, C-reactive protein, and selected minerals and vitamins. Results - Both alcoholic populations suffered from reduced lean body mass $(P=0.001)$, with well-maintained body fat. Magnesium was depleted, and values of vitamin $\mathrm{D}$ and B12 correlated with alcohol abuse. LDL and total cholesterol was increased in alcoholics without pancreatitis $(P=0.04)$, but not in those with visceral damage. C-reactive protein and serum amyloid A correlated with duration of excessive drinking $(P=0.01)$. Conclusions - Undernutrition (diminished lean body mass, risk of magnesium and vitamin deficiencies) contrasted with dyslipidemia and increased cardiovascular risk. This second danger was masked during chronic pancreatitis but not in alcoholics without visceral disease. Further studies should focus special requirements of this population.
\end{abstract}

HEADINGS - Alcoholism. Nutritional status. Sarcopenia. Dyslipidemias. Pancreatitis, alcoholic.

\section{INTRODUCTION}

Alcohol is the most common substance of abuse and it is responsible for $4.4 \%$ of the global burden of disease $^{(24)}$. In contrast to tobacco addiction, consumption is not decreasing and may even be on the rise in parts of the Western world ${ }^{(10)}$.

Alcoholism has been associated with a large number of nutritional and metabolic disorders, both acute and chronic ${ }^{(2,4,22)}$, but it is not obvious how often these are a consequence of an irregular or unbalanced diet, and when they should be accounted on ethanol ingestion per se. Visceral derangements (liver, pancreas, heart, brain) as well as associated medical troubles (tuberculosis, hepatitis, HIV/AIDS, abuse of other chemicals) are not uncommon in immoderate consumers, and might analogously interfere with results of nutritional investigations ${ }^{(13)}$.

Bioimpedance analysis (BIA) and dual-energy absorptiometry have very rarely been employed in such patients, with incomplete consensus about actual impact by the disease ${ }^{(13,19)}$.
Given the interest of the subject and the scarcity of protocols in this area, a preliminary clinical study was designed. The aims were to conduct bioimpedance analysis and define biochemical as well as inflammatory status in alcoholics with and without chronic pancreatitis. The hypothesis was that even in asymptomatic subjects unencumbered by comorbidities, and with acceptable food pattern and nutritional status, alcoholism would still entail adverse repercussions for body composition and biochemical profile.

\section{METHODS}

\section{Ethical considerations}

All patients gave written informed consent, and this protocol was approved by the institutional Ethical Committee.

\section{Population}

Patients with chronic alcoholic pancreatitis confirmed by biochemical profile and imaging procedures (ultrasonography, computed tomography) were investigated. Only males were selected for greater

\footnotetext{
Hospital das Clínicas - HC, Faculdade de Medicina da Universidade de São Paulo - FMUSP, São Paulo, SP, Brasil.

This research received no financial grant . No conflict of interest is declared.

${ }^{1}$ Nutrology Residency Program, HC-FMUSP; ${ }^{2}$ Pancreatic Diseases Service, HC-FMUSP; ${ }^{3}$ Experimental Gastroenterology Laboratory, HC-FMUSP. ${ }^{4}$ Department of Gastroenterology, FMUSP.

Correspondence: Maria B. Sobral, RD - Hospital das Clinicas, ICHC - $9^{\circ}$ andar - sala/9159 - 05403-900 - Sao Paulo, SP, Brasil. E-mail: biasobral@hotmail.com
} 
homogeneity, as they typically represent the majority of such cases.

Alcoholic controls with a negative history for organ damage (pancreas, liver, heart or brain) composed Group II. Healthy controls free from ethanol or other substance abuse (Group III) were recruited as well.

\section{Inclusion criteria}

Requirements were age 18-65 years, clinically stable and asymptomatic, as well as ingesting regular meals or a dietitian-supervised diabetes diet. Exclusion criteria were any alcohol intake in the last 6 months, other chemical dependence, alcoholic cirrhosis, cardiomyopathy or dementia, surgically treated pancreatitis, infection, pseudocyst, fistula, jaundice, intestinal obstruction, consumptive diseases (cancer, tuberculosis, HIV/AIDS, hepatitis B or C, organ failures), previous nutritional diseases (protein-calorie malnutrition, obesity), use of dietary supplements (except for vitamins or minerals), hospitalization for any reason in the last 30 days, and refusal to participate in the protocol.

\section{Exclusions}

Initially 60 subjects (20 in each category) were enrolled, but due to matching requirements concerning Group I (age and BMI) as well as inclusion and exclusion criteria, final numbers in Group II and III were decreased to respectively 12 and $16($ total $=48)$.

\section{Experimental design}

Patients were submitted to an interview that included screening, informed consent, clinical history, nutritional assessment and dietary recall. Research team included a dietitian, a gastroenterologist and a gastroenterological surgeon, with access to other specialists if necessary.

Bioimpedance analysis and biochemical tests were scheduled after an overnight fast. After completed documentation patients were contacted for additional information in case of doubts, inconsistencies or missing results.

\section{Definitions}

Diagnosis of diseases and comorbidities was based on clinical history and current treatment. Alcohol addiction was defined as intake of $>100 \mathrm{~g}$ of ethanol/week ( $>$ two drinks four times a week for a population of moderate risk or concern), in accordance with the CARET protocol ${ }^{(6)}$. Imaging studies along with additional diagnostic procedures were primarily collected from hospital files, however, specialized consultations were requested whenever appropriate.

\section{Dietary intake}

Dietary recall (7 days) was conducted by an experienced dietitian. Reason for this option was previous experience demonstrating differences in drinking pattern not only between weekdays and weekends, but also between ordinary days and those immediately before and after a weekend. Foods and drinks, including snacks and visits to bars and restaurants, were classified on the basis of ingredients, home and commercial portion sizes as well as cooking methods, and industrialized items according to composition. Special attention was given to binge drinking, as well as to miss meals because of lack of funds. Results concerning alcohol and macronutrients were processed by NutWin software (UNIFESP, Sao Paulo, Brazil 2007), encompassing both national and international food databanks TACO, IBGE, TBCA-USP, USDA, CENEXA, German, and General Table of Foods ${ }^{(5)}$.

\section{Diet adequacy}

Daily alimentation was considered adequate if $80 \%$ or more of the recommendations of the American Diabetes Association or of the United States Department of Agriculture (USDA Food pyramid) were fulfilled ${ }^{(3,25)}$.

\section{Lifestyle and physical activities}

Patients at "Hospital das Clínicas" (São Paulo, SP, Brazil) are routinely instructed to lead an active life, employ a healthy diet matched to energy expenditure, and avoid sedentarism. However, no specific investigation was here conducted and no exercise protocol was in use during this study.

\section{Bioimpedance technique}

Body composition was measured by single-frequency ( 50 $\mathrm{kHz}$ ) bioelectrical impedance analysis using a commercial device (BIA Quantum II, RJL Systems, Clinton Township, MI, USA). Four surface electrodes were placed onto clean degreased skin at limb ends in a standardized routine, measurements being performed on the right side of the body.

Tests were conducted in the morning after voiding, by an experienced professional. Total body water (TBW), fat-free mass (FFM) and body fat were calculated using the equations of the apparatus. Normal-weight obesity was defined as BMI $<25 \mathrm{~kg} / \mathrm{m}^{2}$ with body fat percentage over the gender-specific tertile ${ }^{(20)}$.

\section{Laboratory assays}

Hemoglobin, serum albumin, liver and pancreatic enzymes, serum lipids, iron, zinc, phosphate, magnesium, calcium, vitamin $\mathrm{D}$ and vitamin B12 were measured by automated methods. Blood samples were collected in the morning subsequent to overnight fast. The intra- and inter-assay coefficients of variation did not exceed 3\%-6\% for all laboratory techniques.

\section{Inflammatory markers}

Systemic inflammation was monitored by white blood cell count, C-reactive protein, serum amyloid A and leptin.

\section{Statistical analysis}

Analysis of variance (ANOVA) and Kruskall-Wallis test were used according to normality assessment (KolmogorovSmirnov). Linear regression analysis (Pearson or Spearman as required) was employed regarding ethanol consumption and duration. For categorical variables (diabetes, pain) Chisquare analysis or Fischer Exact test were selected. SPSS for Windows, version 10.0, (Chicago, IL, USA) was employed. $P$-values of less than 0.05 were considered significant. 


\section{RESULTS}

Diabetic patients followed the hospital-adopted diet, in compliance with the recommendations of the American Diabetes Association ${ }^{(3)}$. All others informed regularly taking nourishing meals at home, along with occasional vitamin supplements.

Groups were well-matched regarding age and BMI, as pointed out in Table 1, and only males were recruited. Distilled spirits predominated, with long histories and expressive daily intakes, particularly in alcoholics without visceral lesions, which could drink more carelessly. The majority of those with chronic pancreatitis already suffered from diabetes, but pancreatic pain was less conspicuous in this series.

General diet composition was acceptable, with about 1.0$1.2 \mathrm{~g} / \mathrm{kg} /$ day of protein and less than $30 \%$ of the energy in the form of lipids. No patient received dietary supplements or vitamins in the last 3 months. No differences between the groups could be demonstrated (Table 2).

Lean body mass and accompanying body water were diminished in both alcoholic populations (Groups I and II), when compared to controls. Body fat changes were not evident, but resistance, which tends to follow total adipose tissue, was higher in the same 2 groups (Table 3 ). Given the opposing tendencies of lean and fatty tissues, normal-weight obesity might have resulted. Indeed it was detected in both alcoholic populations but the proportion was small.

Inflammatory markers were numerically higher in pancreatitis cases but no significance occurred. A large scatter of the results somewhat interfered with analysis, even though ordinary confusion variables such as infection, inflammation and trauma were routinely ruled out (Table 4).

Few derangements were detected among hepatic and pancreatic enzymes, which were mostly within the expected range, probably because eligibility criteria demanded patients free from exacerbations or ongoing alcoholism, and reporting stable health (Table 5).

By the same token nutritional and metabolic measurements were rarely aberrant in this series, with excellent serum albumin, hemoglobin, calcium and other indices. Exceptions were represented by hyperglycemia and hypomagnesemia in subjects with chronic pancreatitis, along with somewhat elevated total and especially LDL-cholesterol in alcoholics of Group II, without visceral disease (Table 6).

Amount of ethanol intake exhibited correlation with body fat as well as with vitamin B12 concentration, whereas systemic inflammation was a function of duration of dependence (Table 7).

TABLE 1. Preliminary findings

\begin{tabular}{|c|c|c|c|c|}
\hline Description & Pancreatitis & Alcohol & Controls & Significance \\
\hline Age (years) & $54.1 \pm 11.4$ & $55.1 \pm 8.5$ & $54.1 \pm 18.1$ & $P=0.977$ \\
\hline $\mathrm{BMI}\left(\mathrm{kg} / \mathrm{m}^{2}\right)$ & $23.7 \pm 4.6$ & $26.2 \pm 6.8$ & $26.0 \pm 3.7$ & $P=0.202$ \\
\hline \multirow[t]{3}{*}{ Drink type } & Distilled* $50 \%$ & Cognac $66.6 \%$ & & \\
\hline & Beer $40 \%$ & Distilled $* 33.3 \%$ & & \\
\hline & Others $10 \%$ & & & \\
\hline Time (years)** & $21.9 \pm 9.2$ & $24.1 \pm 6.8$ & & $P=0.491$ \\
\hline Ethanol/day (g) & $252.5 \pm 229.1$ & $408.4 \pm 187.4$ & & $P=0.026$ \\
\hline Diabetes & $12 / 20(60 \%)$ & $0 / 12$ & $0 / 16$ & $P=0.000$ \\
\hline Abdominal pain & $7 / 20(35 \%)$ & $0 / 12$ & $0 / 16$ & $P=0.000$ \\
\hline
\end{tabular}

* Distilled sugarcane beverage

** Consumption till discontinuation; currently all patients alcohol-free

TABLE 2. Dietary intake

\begin{tabular}{lcccc}
\hline Component & Pancreatitis & Alcohol & Controls & Significance \\
\hline Total ingestion (kcal/day) & $1637 \pm 546$ & $1645 \pm 310$ & $1622 \pm 542$ & $P=0.897$ \\
Carbohydrate (g/day) & $224 \pm 87$ & $244 \pm 50$ & $225 \pm 79$ & $P=0.759$ \\
Protein (g/day) & $71 \pm 24$ & $62 \pm 14$ & $70 \pm 21$ & $P=0.515$ \\
Lipid (g/day) & $51 \pm 17$ & $48 \pm 14$ & $49 \pm 23$ & $P=0.856$ \\
\hline
\end{tabular}

TABLE 3. Body composition

\begin{tabular}{lcccc}
\hline Measurement & Pancreatitis & Alcohol & Controls & Significance \\
\hline Body fat $(\mathrm{kg})$ & $16.7 \pm 6.3$ & $17.4 \pm 4.3$ & $15.6 \pm 6.2$ & $P=0.713$ \\
Lean body mass $(\mathrm{kg})$ & $51.1 \pm 9.1$ & $53.9 \pm 6.9$ & $61.9 \pm 8.1$ & $P=0.001$ \\
Normal weight obesity & $1 / 20(5 \%)$ & $1 / 12(8.3 \%)$ & $46.3 \pm 6.5$ & $P=0.688$ \\
Body water (L) & $38.4 \pm 6.5$ & $40.1 \pm 5.2$ & $441 \pm 51$ & $P=0.002$ \\
Resistance $(\mathrm{ohm})$ & $540 \pm 80$ & $522 \pm 56$ & $62 \pm 16$ & $P=0.000$ \\
Reactance $(\mathrm{ohm})$ & $71 \pm 27$ & $86 \pm 30$ & $P=0.062$ \\
\hline
\end{tabular}


TABLE 4. Inflammatory markers

\begin{tabular}{lcccc}
\hline Variable & Pancreatitis & Alcohol & Controls & Significance \\
\hline C-reactive protein $(\mathrm{mg} / \mathrm{L})$ & $4.8 \pm 7.2$ & $3.8 \pm 4.4$ & $2.7 \pm 1.9$ & $P=0.529$ \\
Serum amyloid A $(\mathrm{mg} / \mathrm{L})$ & $5.5 \pm 5.9$ & $5.1 \pm 4.3$ & $4.4 \pm 3.1$ & $P=0.648$ \\
Leptin $(\mathrm{ng} / \mathrm{L})$ & $4.7 \pm 6.0$ & $4.0 \pm 1.7$ & $6.8 \pm 3.5$ & $P=0.267$ \\
WBC* $\left(\mathrm{X} 10^{3} / \mathrm{mL}\right)$ & $7.7 \pm 2.1$ & $5.9 \pm 2.1$ & $6.0 \pm 1.0$ & $P=0.070$ \\
\hline
\end{tabular}

* WBC - White blood cell count

TABLE 5. Hepatobiliary and pancreatic enzymes

\begin{tabular}{lcccc}
\hline Enzyme & Pancreatitis & Alcohol & Controls & Significance \\
\hline Amylase (U/L) & $81 \pm 63$ & $72 \pm 37$ & $71 \pm 24$ & $P=0.920$ \\
Lipase (U/L) & $25.3 \pm 24.4$ & $30.3 \pm 10.3$ & $32.0 \pm 8.2$ & $P=0.055$ \\
Aspartate aminotransferase (U/L) & $24.4 \pm 6.0$ & $21.5 \pm 4.6$ & $24.3 \pm 8.9$ & $P=0.406$ \\
Alanine aminotransferase (U/L) & $27.5 \pm 15.5$ & $22.3 \pm 9.2$ & $25.1 \pm 7.1$ & $P=0.671$ \\
Gamma-glutamyl transferase (U/L) & $42.0 \pm 26.2$ & $56.1 \pm 78.9$ & $34.7 \pm 24.1$ & $P=0.515$ \\
\hline
\end{tabular}

TABLE 6. General biochemical and nutritional indices

\begin{tabular}{|c|c|c|c|c|}
\hline Variable & Pancreatitis & Alcohol & Controls & Significance \\
\hline Albumin $(\mathrm{g} / \mathrm{dL})$ & $4.0 \pm 0.5$ & $4.1 \pm 0.4$ & $4.3 \pm 0.3$ & $P=0.882$ \\
\hline Hemoglobin (g/dL) & $14.5 \pm 1.2$ & $14.9 \pm 0.7$ & $14.9 \pm 1.1$ & $P=0.412$ \\
\hline Total cholesterol (mg/dL) & $163 \pm 35$ & $197 \pm 22$ & $175 \pm 36$ & $P=0.026$ \\
\hline $\operatorname{VLDL}(\mathrm{mg} / \mathrm{dL})$ & $25.2 \pm 12.9$ & $23.4 \pm 10.7$ & $24.5 \pm 15.8$ & $P=0.795$ \\
\hline $\mathrm{LDL}(\mathrm{mg} / \mathrm{dL})$ & $92 \pm 34$ & $125 \pm 27$ & $102 \pm 37$ & $P=0.040$ \\
\hline $\mathrm{HDL}(\mathrm{mg} / \mathrm{dL})$ & $45.5 \pm 14.9$ & $48.7 \pm 19.4$ & $48.1 \pm 17.5$ & $P=0.841$ \\
\hline Triglycerides (mg/dL) & $117 \pm 43$ & $117 \pm 53$ & $123 \pm 79$ & $P=0.952$ \\
\hline Glucose (mg/dL) & $138 \pm 64$ & $94 \pm 14$ & $94 \pm 13$ & $P=0.020$ \\
\hline Iron $(\mu \mathrm{g} / \mathrm{dL})$ & $83 \pm 22$ & $94 \pm 22$ & $104 \pm 28$ & $P=0.057$ \\
\hline $\operatorname{Zinc}(\mu \mathrm{g} / \mathrm{dL})$ & $83 \pm 18$ & $91 \pm 16$ & $82 \pm 12$ & $P=0.272$ \\
\hline Phosphorus (mg/dL) & $3.5 \pm 0.5$ & $3.3 \pm 0.6$ & $3.1 \pm 0.4$ & $P=0.088$ \\
\hline Calcium (mg/dL) & $9.2 \pm 1.3$ & $9.5 \pm 0.7$ & $9.5 \pm 0.5$ & $P=0.632$ \\
\hline Magnesium (mg/dL) & $1.9 \pm 0.3$ & $2.2 \pm 0.2$ & $2.3 \pm 0.2$ & $P=0.042$ \\
\hline Vitamin D (ng/mL) & $31.4 \pm 15.0$ & $23.3 \pm 7.9$ & $27.8 \pm 9.4$ & $P=0.279$ \\
\hline Vitamin B12 (pg/mL) & $612 \pm 350$ & $395 \pm 119$ & $607 \pm 394$ & $P=0.149$ \\
\hline
\end{tabular}

VLDL: Very low density cholesterol; LDL: Low density cholesterol; HDL: High density cholesterol

TABLE 7. Correlations with alcohol addiction (Groups I + II)

\begin{tabular}{lcc}
\hline Duration of abuse & $\mathbf{r}$ & Significance \\
\hline C-reactive protein & -0.455 & $P=0.009$ \\
Serum amyloid A & -0.438 & $P=0.011$ \\
Vitamin D & -0.347 & $P=0.049$ \\
\hline Volume of intake & $\mathbf{r}$ & Significance \\
\hline Body fat \% & -0.352 & $P=0.048$ \\
Vitamin B12 & -0.465 & $P=0.008$ \\
\hline
\end{tabular}

\section{DISCUSSION}

Consumption of ethanol in this series was immoderate, reaching around $400 \mathrm{~g}$ /day in Group II. In other words, more than $100 \%$ of the daily energy requirement $(2800 \mathrm{kcal})$ was provided by this substrate, leaving comparatively little room for other foods.

Sequelae of previous overindulgence in calories could be inferred from bioimpedance analysis, in the form of elevated resistance, which usually follows body fat, and in the case alcoholics without visceral damage also by higher total and LDL-cholesterol. 
Body fat was expected to be elevated not only in the relative sense, because of shrinkage of lean body mass. Given the substantial energy value of the addiction, patients should bear voluminous lipid deposits. Such speculations notwithstanding, they were in better physical and metabolic shape than anticipated. Indeed, obesity has never been frequent in the most abusive drinkers, namely those of low social class. Even better-off cases with access to good food only rarely gain huge amounts of weight. "Skid row" patients may even display severe protein-calorie malnutrition ${ }^{(4)}$.

Regression analysis confirmed that ethanol consumption was significantly but negatively linked to adipose tissue accumulation (Table 7). Counter intuitively, subjects who drank more exhibited less body fat.

Recent investigations attempted to attribute the paradox to cortisol, which tends to be elevated during hazardous drinking and also negatively correlates with fat mass ${ }^{(19)}$. It is unlikely that this hormone is responsible because corticosteroids are associated with fat anabolism, not catabolism, and obesity is a classic feature of Cushing's syndrome (adrenal hypercortisolism).

Actually, many more appetite-related and volume-regulating hormones seem do be deranged in alcoholics ${ }^{(1,19)}$. It is also worth mentioning that in some series, fat mass accumulation was not impaired ${ }^{(13)}$.

Normal or mildly increased body fat compartment contrasted with conspicuous reduction of lean body mass. Albeit an uncomfortable context for the patient because it tends to be associated with metabolic syndrome, there is insufficient information to predict how many cases of normal-weight obesity and its attending sequelae might actually result in such circumstances ${ }^{(5)}$.

Nevertheless, alcoholics without pancreatitis carried the burden of total and LDL-cholesterol elevation. It has been underscored that moderate alcohol consumption lowers the risk for diabetes in women, whereas the opposite occurs in cases of massive drinking ${ }^{(7)}$. Also in comparatively young adults admitted to a drug treatment facility, a clustering of cardiovascular risk factors such as dyslipidemia, sedentarism and metabolic syndrome was highlighted ${ }^{(17)}$.

In parallel with normal or mildly elevated body fat depots, lean body mass erosion was a concern. Ethanol does not often impair muscle mass in experimental animals. However, if sedentarism and disuse atrophy is induced by casting of a limb, alcohol consumption will enhance muscle loss by $80 \%$, in association with increased expression of atrogin-1 mRNA, reduction in 4E-BP1 and S6 phosphorylation, and increased AMP-activated kinase phosphorylation ${ }^{(26)}$.

Even in freely-moving rats, alcohol intoxication might blunt the anabolic effects of amino acids in muscle tissue, nominally in the form of leucine resistance, as evidenced by the impaired phosphorylation of 4E-BP1, eIF4G, S6K1, and $\mathrm{mTOR}^{(18)}$.

Persistent inflammation could also be a trigger of muscle wasting, as demonstrated not only in serious illnesses such as dialysis-requiring renal disease, heart insufficiency and chronic obstructive lung disease, but also in the standard aging process. TNF-alpha could be one of the underlying mechanisms, as this pro-inflammatory cytokine destabilizes MyoD, a muscle-specific transcription factor involved in satellite cell proliferation and differentiation, thus downregulating muscle regenerating capacity ${ }^{(9)}$.

Sarcopenia is well known in the classic Líber-De Carli model of murine alcoholism, however besides ethanol itself, other mechanisms could be involved such as oxidative stress, deficiency of magnesium or of vitamin $\mathrm{D}^{(14,22,24)}$.

Systemic inflammation was not overt in this series and did not directly match bioimpedance results, yet correlation with alcohol ingestion was robust $(P=0.009$ for $\mathrm{C}$-reactive protein, $P=0.011$ for serum amyloid A).

Magnesium deficiency as here registered is another wellknown abnormality in alcoholics, and replenishment has been suggested to attenuate withdrawal syndrome ${ }^{(16)}$. Low concentrations of B-complex and D vitamin are not uncommon either ${ }^{(2,4,27)}$. Vitamin B12, vitamin D, zinc and iron remained within the expected range, but the two vitamins significantly correlated with alcoholism.

To the best of our knowledge, this is the first controlled investigation revealing that body composition and nutritional profile in asymptomatic individuals with access to a satisfactory diet, either without manifestations of organ damage or well compensated from this point of view, suffer an adverse impact of alcohol excess.

Most clinical studies about malnutrition in alcoholics do not separate subjects with visceral disease from those without, or consequences of simply reduced energy intake from more specific alcohol effects ${ }^{(8)}$. Few classic studies have been updated, references in modern surveys about protein-calorie and vitamin deficits often being 10-20 years old ${ }^{(15,21)}$. Only 2 series with disease-free addicted controls could be found ${ }^{(12,23)}$, addressing liver cirrhosis, not pancreatitis. In both of them alcoholics without visceral damage were classified as nutritionally normal, with just diminished skinfold fat in one of them ${ }^{(23)}$.

Studied patients were not active drinkers anymore, were not hospitalized and exhibited no acute disease, nevertheless they still carried a burden in the form of depressed lean body mass along with additional nutritional and metabolic aberrations.

Diabetes and abdominal pain could not be incriminated for such an outcome because similar findings were proven in alcoholics without pancreatic disease.

Our results emphasize a double jeopardy in the sense that diminished lean body mass or sarcopenia combined with potential vitamin deficiencies and hypomagnesemia was conspicuous, and consistent with undernutrition. At the same time, systemic inflammation and elevated cardiovascular risk in line with dyslipidemia and relatively increased body fat could not be ruled out.

Additional studies should elucidate whether these hazards taper off or conversely persist as vulnerability in later periods even if total withdrawal is maintained, and optimal dietetic intake is assured. Available evidence regarding systemic inflammation and cardiovascular profile is not exceedingly optimistic, with signs of continued risk during several years despite complete abstinence ${ }^{(11)}$. 


\section{CONCLUSIONS}

A two-tiered nutritional and metabolic danger was unveiled, in the form of undernutrition (diminished lean body mass, magnesium and vitamin deficiencies) combined with dyslipidemia and increased probability of cardiovascular complications. This second abnormality was masked during chronic pancreatitis but not in drinkers without visceral disease.
As expected chronic pancreatitis entailed specific derangements (diabetes, abdominal pain, potentially malabsorption) related to organ destruction, not specifically to ethanol. However, disease-free addicted persons with acceptable dietary ingestion displayed an abnormal phenotype as well. Further studies should focus nutritional and metabolic requirements of these populations, notably concerning long-term clinical course of sarcopenia and dyslipidemia.

Sobral-Oliveira MB, Faintuch J, Guarita DR, Oliveira CP, Carrilho FJ. Perfil nutricional de pacientes alcoólatras assintomáticos. Arq Gastroenterol. 2011;48(2);112-8.

RESUMO - Contexto - O alcoolismo pode interferir no estado nutricional, todavia, os relatos frequentemente sofrem com o viés das incertezas sobre dieta consumida, danos orgânicos subjacentes e persistência do abuso. Objetivo - Para identificar alterações nutricionais e de compartimentos corpóreos em alcoólatras estáveis sem variáveis de confusão clínica e dietética, foi desenhado o presente estudo piloto observacional prospectivo. Três populações bem pareadas foram consideradas: casos de pancreatite crônica alcoólica, alcoólatras sem enfermidade visceral e adultos que nunca consumiram etanol (controles). Métodos - Os pacientes $(n=60)$ eram homens assintomáticos com dieta satisfatória, nenhuma evidência de enfermidade ou complicação exceto as do protocolo e afastados do etanol por no mínimo 6 meses. Após exclusões, 48 pacientes foram comparados. As variáveis abrangeram recordatório alimentar, análise de bioimpedância, perfil bioquímico e marcadores inflamatórios. Os principais resultados buscados foram gordura corporal, massa magra, lípides séricos, proteína C reativa e vitaminas e minerais selecionados. Resultados - Os dois grupos que ingeriam álcool exibiram redução da massa magra $(P=0,001)$ com gordura corporal bem conservada. O magnésio estava diminuído e as taxas de vitamina D e B12 se correlacionaram com o abuso de álcool. O colesterol total e LDL estavam aumentados nos alcoólatras sem pancreatite ( $P$ = 0,04), porém, não naqueles com dano pancreático. A proteína $\mathrm{C}$ reativa e o seroamilóide A correlacionaram-se com a duração do excesso etílico $(P=0,01)$. Conclusões - A desnutrição (menor massa magra, possibilidade de carência de magnésio e vitaminas) contrastou com a dislipidemia e o risco cardiovascular elevado. Este segundo perigo permaneceu mascarado na vigência de pancreatite crônica, porém, não nos alcoólatras sem lesão visceral. Estudos adicionais deverão focalizar as necessidades nutricionais específicas desta população.

DESCRITORES - Alcoolismo. Estado nutricional. Sarcopenia. Dislipidemias. Pancreatite alcoólica.

\section{REFERENCES}

1. Addolorato G, Leggio L, Hillemacher T, Kraus T, Jerlhag E, Bleich S. Hormones and drinking behaviour: new findings on ghrelin, insulin, leptin and volume-regulating hormones. An ESBRA symposium report. Drug Alcohol Rev. 2009;28:160-5.

2. Al-Sanouri I, Dikin M, Soubani AO. Critical care aspects of alcohol abuse. South Med J. 2005;98:372-81.

3. American Diabetes Association, Bantle JP, Wylie-Rosett J, Albright AL, Apovian CM, Clark NG, Franz MJ, Hoogwerf BJ, Lichtenstein AH, Mayer-Davis E, Mooradian AD, Wheeler ML. Nutrition recommendations and interventions for diabetes: a position statement of the American Diabetes Association. Diabetes Care. 2008;31 Suppl 1:S61-78

4. Ashley MJ, Olin JS, Le Riche WH, Kornaczewski A, Schmidt W, Rankin JG. Social class and morbidity in clinically treated alcoholics. Drug Alcohol Depend. 1976;4:263-76

5. Barnes AJ, Moore AA, Xu H, Ang A, Tallen L, Mirkin M, Ettner SL. Prevalence and correlates of at-risk drinking among older adults: the project SHARE study. J Gen Intern Med. 2010;25:840-6.

6. Bistriche Giuntini E, Lajolo FM, Wenzel de Menezes E. [Brazilian food composition table TBCA-USP (versions 3 and 4) in the international context]. Arch Latinoam Nutr. 2006;56:366-74.

7. Carlsson S, Hammar N, Grill V, Kaprio J. Alcohol consumption and the incidence of type 2 diabetes: a 20 -year follow-up of the finnish twin cohort study. Diabetes Care. 2003;26:2785-90.

8. Carvalho L, Parise ER. Evaluation of nutritional status of nonhospitalized patients with liver cirrhosis. Arq Gastroenterol. 2006;43:269-74.

9. Degens H. The role of systemic inflammation in age-related muscle weakness and wasting. Scand J Med Sci Sports. 2010;20:28-38.

10. Department of Health. Safe, sensible social-consultation on further action. London, UK: Department of Health; 2008.

11. Di Gennaro C, Biggi A, Barilli AL, Fasoli E, Carra N, Novarini A, Delsignore R, Montanari A. Endothelial dysfunction and cardiovascular risk profile in long-term withdrawing alcoholics. J Hypertens. 2007;25:367-73.
12. García-Valdecasas-Campelo E, González-Reimers E, Santolaria-Fernández F, De La Vega-Prieto MJ, Milena-Abril A, Sánchez-Pérez MJ, Martínez-Riera A, Rodríguez-Rodríguez E. Brain atrophy in alcoholics: relationship with alcohol intake; liver disease; nutritional status, and inflammation. Alcohol Alcohol. 2007; $42: 533-8$

13. González-Reimers E, García-Valdecasas-Campelo E, Santolaría-Fernandez F, Sánchez-Pérez MJ, Rodríguez-RodríguezE, Gómez-Rodríguez MA, Viña-Rodríguez J. Prognostic value of nutritional status in alcoholics assessed by doube-energy X-ray absorptiometry. Alcohol Alcohol. 2008;43:314-9.

14. González-Reimers E, Durán-Castellón MC, López-Lirola A, Santolaria-Fernández F, Abreu-González P, Alvisa-Negrín J, Sánchez-Pérez MJ. Alcoholic myopathy: vitamina D deficiency is related to muscle fibre atrophy in a murine model. Alcohol Alcohol. 2010:45:223-30

15. Halsted CH. Nutrition and alcoholic liver disease. Semin Liver Dis. 2004;24: 289-304

16. Hornyak M, Haas P, Veit J, Gann H, Riemann D. Magnesium treatment of primary alcohol-dependent patients during subacute withdrawal: an open pilot study with polysomnography. Alcohol Clin Exp Res. 2004;28:1702-9.

17. Jarvis CM, Hayman LL, Braun LT, Schwertz DW, Ferrans CE, Piano MR Cardiovascular risk factors and metabolic syndrome in alcohol- and nicotinedependent men and women. J Cardiovasc Nurs. 2007;22:429-35.

18. Lang CH, Frost RA, Deshpande N, Kumar V, Vary TC, Jefferson LS, Kimball SR. Alcohol impairs leucine-mediated phosphorylation of 4E-BP1, S6K1, eIF4G, and mTOR in skeletal muscle. Am J Physiol Endocrinol Metab. 2003;285: E1205-15.

19. Leggio L, Malandrino N, Ferrulli A, Cardone S, Miceli A, Gasbarrini G, Capristo $\mathrm{E}$, Addolorato G. Is cortisol involved in the alcohol-related fat mass impairment? A longitudinal clinical study. Alcohol Alcohol. 2009;44:211-5.

20. Marques-Vidal P, Pécoud A, Hayoz D, Paccaud F, Mooser V, Waeber G, Vollenweider P. Normal weight obesity: relationship with lipids, glycaemic status, liver enzymes and inflammation. Nutr Metab Cardiovasc Dis. 2009;10:217-21.

21. Moreno Otero R, Cortés JR. [Nutrition and chronic alcohol abuse]. Nutr Hosp. 2008;23 (Suppl 2):3-7. 
22. Otis JS, Guidot DM. Procysteine stimulates expression of key anabolic factors and reduces plantaris atrophy in alcohol-fed rats. Alcohol Clin Exp Res. 2009;33:14509.

23. Panagaria N, Varma K, Nijhawan S, Mathur A, Rai RR. Quality of life and nutritional status in alcohol addicts and patients with chronic liver disease. Trop Gastroenterol. 2007;28:171-5.

24. Romani AM. Magnesium homeostasis and alcohol consumption. Magnes Res. 2008;21:197-204
25. US Department of Agriculture, Center for Nutrition Policy and Promotion, Sample Menus for a 2000 Calorie Food Pattern; 2006. Available from: <www. MyPyramid.gov>.

26. Vargas $\mathrm{R}$, Lang $\mathrm{CH}$. Alcohol accelerates loss of muscle and impairs recovery of muscle mass resulting from disuse atrophy. Alcohol Clin Exp Res. 2008;32 128-37.

27. Walker L, Brown P, Beeching NJ, Beadsworth MB. Managing alcohol withdrawal syndromes: the place of guidelines. Br J Hosp Med (Lond). 2009;70:444-9.

Received 8/10/2010 Accepted 10/11/2010 